\title{
Kapari bitkisinin bioaktif, farmakolojik etkileri ve nörodejeneratif hastalıklarda kullanımı
}

\author{
Asim KART
}

Burdur Mehmet Akif Ersoy Üniversitesi, Veteriner Fakültesi, Farmakoloji ve Toksikoloji Anabilim Dalı, Burdur/TÜRKIYYE

\author{
Anahtar Kelimeler: \\ kapari \\ fitokimyasal \\ nörodejenerayon
}

Key Words:

capers

phytochemical

neurodegeneration

Gelis Tarihi: 04.09.2019

Kabul Tarihi: 17.11.2019

Yay1n Tarihi: 31.12.2019

Makale Kodu: 615592

Sorumlu Yazar:

A. KART

(akart@mehmetakif.edu.tr)

ORCİD:

A. KART: 0000-0002-5227-1289

\section{ÖZ}

Kapari olarak bilinen Capparidaceae ailesine ait bitki türleri başlica dünyanın sıcak bölgelerinde yayg1n olup, Capparis spinosa (C. spinosa), Capparis ovata (C. spinosa) ve Capparis decidua (C. decidua) terapötik ve besinsel özellikleri yönünden en yaygın araştırılan türleridir. Bitki yapısında birçok fitokimyasal içermekte olup, farmakolojik ve terapötik etkilerinden dolayı halk arasında birçok hastalığın tedavisinde kullanılmıştır. İçeriğinde alkaloidler ve fitosteroller, flavanoidler, fenolik asitler, glikosinolatlar, antioksidanlar, quarterner amonyum bileşikleri ve vitaminlerin bulunduğu tespit edilmiştir. Kapari bitkisinin yaprak ve tomurcuklarının fenolik bileşiklerden oldukça zengindir. Bu bileşikler serbest radikal süpürücü özelliklere sahiptir ve içerdiği fenolik bileşikler önemli bir fitokimyasal antioksidan grubunu oluşturmaktadır. C. spinosa önemli miktarda rutin ve quercetin içermektedir. Yapılan çalışmalarda kaparinin analjezik, anti-inflamatuar, antioksidan, antitümöral, diüretik, antidiyaretik, hipoglisemik, balgam söktürücü, antibakteriyel, antialerjik, antihipertansif, antifungal, antihiperlipidemik etkileri gösterilmiştir. Bu etkilerinin yanı sıra kapari ailesine ait bitki türlerinin sinir doku üzerinde görülen ve tedavi olanaklarının sınırlı olduğu bazı nörodejeneratif bozukluklarda etkilerinin olduğu da son yıllarda bildirilmektedir. Kapari türlerinin sedatif, antikonvülsant, analjezik, antiepileptik etkilerinin olduğu ve multiple sclerosis, Alzheimer ve diğer merkezi sinir sisteminin nörodejeneratif tipte hastalıklarında faydalı ve tedavi edici etkilerinin olduğu rapor edilmiştir. Yapılan çalışmalar ve bunların sonucu kapari bitkisinin bu tip bozukluklarda umut vaat eden alternatif bir tedavi aracı olarak kullanılabileceğini göstermektedir.

\section{Bioactive, pharmacological effects of caper plant and its use in neurodegenerative diseases}

\begin{abstract}
The plant species belonging to the Capparidaceae family, known as Capers, are widespread in the warm regions of the world. Capparis spinosa (C. spinosa), Capparis ovata (C. spinosa) and Capparis decidua are the most widely studied in terms of their therapeutic and nutritional properties. It contains many phytochemicals in its plant structure and has been used in the treatment of many diseases as folk medicine due to its pharmacological and therapeutic effects. It contains alkaloids and phytosterols, flavonoids, phenolic acids, glycosinolates, antioxidants, quarternary ammonium compounds and vitamins. The leaves and buds of the caper plant are rich in phenolic compounds. These compounds have free radical scavenging properties and the phenolic compounds they contain constitute an important group of phytochemical antioxidants. C. spinosa contains a significant amount of routine and quercetin. Analgesic, anti-inflammatory, antioxidant, antitumoral, diuretic, antidiuretic, hypoglycemic, expectorant, antibacterial, antiallergic, antihypertensive, antifungal, antihyperlipidemic effects have been shown in the studies. In addition to these effects, it has been reported in recent years that plant species belonging to the caper family have effects on some neurodegenerative disorders that are seen on nerve tissue and treatment options are limited. Caper species have been reported to have sedative, anticonvulsant, analgesic, antiepileptic effects, and have beneficial and therapeutic effects in neurodegenerative type diseases of multiple sclerosis, Alzheimer's and other central nervous system. Studies and their results show that capari plant can be used as a promising alternative treatment tool for such disorders.
\end{abstract}

\section{GİRIŞ}

Bitkiler geçmişten günümüze kadar insanlar tarafindan tedavi amaçla kullanılmıştır. Son yıllarda yapılan çalışmalarda bitkilerin insan sağllğ̆ üzerinde önemli etkilerinin vurgulanmasıyla birlikte modern tıpta kullanılan birçok ilaçta da bitkiler kullanılmaya başlanmıştır (1). Özellikle ülkemizin sahip olduğu zengin bitki örtüsü nedeniyle dünyaya oranla ülkemizde bu amaçla kullanılan bitki sayısı artmıştır. Bu bitkilerden biri de ülkemizde ve Akdeniz mutfağında yayg1n olarak kullanılan Capparis türleridir. Kapari adı Capparidaceae ailesinden capparis cinsine verilen genel bir isimdir. Bu bitkinin özellikleri yüzyıllardır bilinmektedir (2). İlk kullanımı Sümerler tarafindan, daha sonra Yunanlılar ve Romalılar tarafindan M.Ö. 2000'li y1llarda tıbbi amaçlar için olmuştur (3). Kapari başlica dünyanin sicak bölgelerinde yayg1n olup, 39 cins ve 650 türden oluşur. Bu türler arasında Capparis spinosa (C. spinosa), Capparis 
ovata (C. spinosa) ve Capparis decidua (C. decidua) terapötik ve besinsel özellikleri yönünden en yaygın araştırılanlarıdır (4). Türkiye'de kapari bitkisine bubu, gebre, cambar, kebere ve turşuotu gibi isimler verilmiştir (5). Kapari bitkisi 30-100 cm aras1 uzunlukta olup, 6-10 m ye kadar kök salabilen, 2-5 cm uzunluğunda, oval-eliptik yaprakları olan bir bitkidir (2). Kapari bitkisinin olgunlaşmış meyvesini içeren genel görünümü Şekil 1'de verilmiştir.

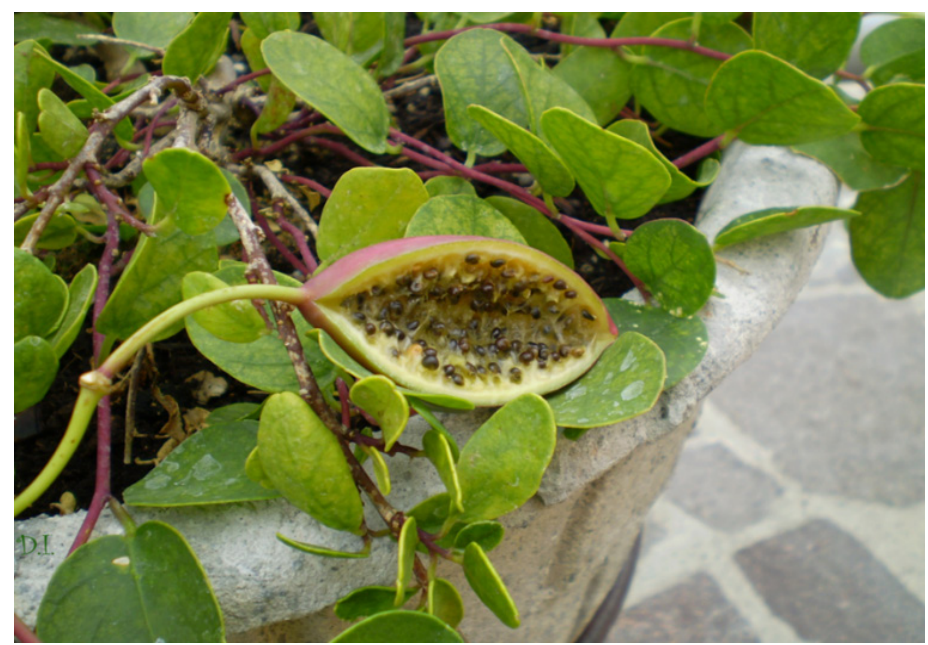

Şekil 1 Kapari bitkisinin olgunlaşmıș meyvesi ve yaprakları (45)

Kök kabuğu içinde bulundurduğu bileşikler açısından bitkinin en aktif kısmıdır. Tıbbi ve aromatik özellikleri olan bu bitkinin çiçeği, meyvesi, yaprakları ve kökleri halk arasında ilaç olarak kullanılmıştır $(5,6)$. Yapılan çalışmalarda Capparidaceae familyasına ait bitki türlerinin yapısında bulunan çok sayıda biyoaktif bileşik sayesinde bu bitkinin hastalıkların tedavisinde potansiyel olarak önemli birçok terapötik etkilere sahip olduğu bilinmektedir (7). Kaparinin analjezik, anti-inflamatuar, antioksidan, antitümöral, diüretik, antidiyaretik, hipoglisemik, balgam söktürücü, antibakteriyel, antialerjik, antihipertansif, antifungal, antihiperlipidemik etkileri çeşitli çalışmalarda bildirilmiştir (1-3, 7-14). Günümüzde sinir sistemini etkileyen birçok toksik, metabolik, genetik ve bağışıklık sistemi kaynaklı faktör bulunmaktadır. Bu etkenlerin sinir sistemi üzerinde oluşturduğu hastalıklar ve bozukluklar günümüz tıbbında önemli bir sorun olarak görülmektedir. Bunlar arasında Özellikle Multiple Skleroz (MS) gibi myelin kaybiyla karakterize ve ilerleyici tipteki nörodejeneratif hastalıklar önemli bir sorun teşkil etmekte olup, henüz tam bir sağaltım imkanı yoktur (15). Kapari familyasına ait bitki türlerinin bu türden hastalıkların tedavisinde kullanılabileceği ve potansiyel olarak önemli bir terapötik ajan olarak değerlendirilebileceği bildirilmiştir. $\mathrm{Bu}$ makalede kapari familyasına ait bitki türlerinin bioaktif, farmakolojik etkileri ve nörodejeneratif hastalıklarda kullanımı ile ilgili literatür bilgileri derlenmiştir.

\section{Kapari Bitkisinin Besinsel Özellikleri}

Kapari protein, karbonhidrat, yağ, vitamin ve mineraller açısından besleyici ve zengin içeriğe sahip bir bitkidir (3, 4). Genç sürgünleri, çiçekleri, meyveleri ve tomurcukları beslenmede önemli yere sahiptir bu nedenledir ki bu bitkinin ürünlerine son yıllarda talep artmış, ekonomik açıdan önemli hale gelmiştir (5).

Yapılan çalışmalar ve araştırmalar kaparinin içeriğinde bulunan yağ, protein, mineraller ve vitaminlerle yeni bir besin kaynağ1 olarak kullanılabileceğini göstermektedir (5). Bitkinin sap ve meyvelerinde mineral içerik olarak farklı oranlarda olmak üzere fosfor, magnezyum, demir, çinko, bakır, sodyum ve kalsiyum bulunduğu bildirilmiştir. Kapari türleri vitamin içeriği açısından da oldukça zengindir (4). Kapari bitkisinin en yaygın bulunan iki ayrı türünün besinsel içeriği ve miktarları Tablo 1'de verilmiştir.

Tablo 1 Capparis spinosa ve Capparis ovata bitki türlerinin besinsel özellikleri (3-5).

\begin{tabular}{lccc}
\hline \multicolumn{1}{c}{ İçerik } & Birim & C.spinosa & C. Ovata \\
\hline Su & $\%$ & 6.50 & 8.60 \\
Protein & $\%$ & 20.23 & 19.55 \\
Yağ & $\%$ & 27.74 & 28.66 \\
Selüloz & $\%$ & 28.24 & 29.67 \\
Karbonhidrat & $\%$ & 71.00 & - \\
& & & \\
C vitamini & $\mathrm{mg} / 100 \mathrm{~g}$ & 0.54 & 8.80 \\
$\mathrm{Ca}$ & $\mathrm{mg} / \mathrm{kg}$ & 2100 & - \\
$\mathrm{Fe}$ & $\mathrm{mg} / \mathrm{kg}$ & 60 & - \\
$\mathrm{Zn}$ & $\mathrm{mg} / \mathrm{kg}$ & 40 & - \\
\hline
\end{tabular}

\section{Kapari Bitkisinin Yapısında Bulunan Fitokimyasallar}

Kapari bitkisinin içinde farklı biyoaktif etkilere sahip moleküller ve yapılar vardır. İçeriğinde alkaloidler ve fitosteroller, flavanoidler, fenolik asitler, glikosinolatlar, antioksidanlar, quarterner amonyum bileșikleri ve vitaminlerin bulunduğu gösterilmiştir (4, 16-19).

Alkaloid içerik açısından yapısında bulunan spermidin alkaloidi birçok biyolojik fonksiyona ve potansiyel terapötik etkilere sahip bir molekül olarak gösterilmiştir. Örneğin spermidin alkaloidinin hücrelerde üreme, gelişme, büyüme ve çoğalmada önemli roller oynadığı bildirilmiştir (4, 20). Aynı zamanda içeriğinde bulunan poliamin alkaloidlerin antioksidan, antiallerjenik, arteriosklerozu önleyici, sağlıklı saç büyümesini teşvik edici, anti-inflamatuar etkilere sahip olduğu gösterilmiștir. Fitosterol olarak bulunan $\beta$-sitosterol, siklooksijenaz ve 5 -lipooksijenaz yolaklarını inhibe ederek antiinflamatuar etkiye yol açtığ bildirilmiştir $(1,4,21)$.

Yapılan çalışmalar kapari bitkisinin yaprak ve tomurcuklarının fenolik bileşiklerden oldukça zengin olduğunu göstermiştir. $\mathrm{Bu}$ bileşiklerin biyolojik etkileri ve serbest radikal süpürücü özelliklere sahiptir ve içerdiği fenolik bileşikler önemli bir fitokimyasal antioksidan grubunu oluşturmaktadır (3, 22). C. spinosa önemli miktarda rutin ve quercetin içermektedir, bu açıdan önemli ticari bir kaynaktır. P vitamini olarakta bilinen rutin bitkisel kaynaklı fenolik bileşiktir. Zira bu madde antioksidan, anti-inflamatuar ve antikarsinojenik etkisinin 
yanında damar yapısının bozulmasını önlemektedir $(3,23)$.

Kapariden gelen aktif bileşiklerin bir kısmıda glukosinolatlardır. Kaparide neo-glukobrassisin, 4-methoxyglukocapparine, sinigrin, 1-metoksi 3-indomethyl ve glukobrassisin gibi farklı glukosinolatlar tanımlanmıştır. Glukosinolatlar birçok bitkide bulunan biyolojik olarak aktif maddelerdir (24, 25). On iki farkl1 glukosinolat C. spinosa ve C.ovatadan izole edilmiştir. Bunlar içerisinde toplam glikosinolat oranının \% 90'nını glucocapperin oluşturmaktadır. Glukosinolatlar göreceli olarak toksik olmayan fakat bazı yan etkiler oluşturabilen maddelerdir. Bunlar arasında büyüme ve üreme üzerinde olumsuz etkiler oluşturup hayvanlarda performans kaybına neden olabileceği bildirilmiştir. Diğer taraftan brasica bitkisinde bulunan glukosinolatların antikarsinojenik aktiviteden sorumlu molekül olduğu da bilinmektedir (24-27).

Kapari bitkisi E grubu vitaminlerinden olan tokoferol ve karatenoidler açısından da zengindir. Bu vitaminlerin kanser, kardiyovasküler bozukluklar ve aterosklerozis gibi kronik ve dejeneratif hastalıklar riskini azalttığı bilinmektedir. Kapari ayrıca önemli miktarda $C$ vitamini içermektedir, bu vitaminin organizmada demir emilimi, nitrozamin oluşumunun engellenmesi ve bağ1şıklı sistemini kuvvetlendirmesi gibi önemli rolleri vardır (3). Tablo 2'de kapari bitkisinin fitokimyasallar yönünden içeriği verilmiştir.

Tablo 2 Capparis spinosa ve Capparis ovatanm yapisinda bulunan fitokimyasallar $(3,25)$.

\begin{tabular}{lccc}
\hline İçerik & Birim & C. spinosa & C. ovata \\
\hline Total Fenol & $\mathrm{mg} / 100 \mathrm{~g}$ & 1.98 & 1.76 \\
Total Karetenoid & $\mathrm{mg} / 100 \mathrm{~g}$ & 3.91 & - \\
Total & $\%$ & 83.43 & 83.72 \\
Rutin & $\mathrm{mg} / 100 \mathrm{~g}$ & 1352.71 & - \\
Tokoferol & $\mathrm{mg} / 100 \mathrm{~g}$ & 40.48 & - \\
Vitamin C & $\mathrm{mg} / 100 \mathrm{~g}$ & 0.1 & - \\
\hline
\end{tabular}

\section{Kapari Türlerinin Farmakolojik ve Biyoaktif Etkileri}

Yapılan çeşitli çalışmalar kapari türünün önemli antiinflamatuar aktiviteye sahip olduğunu göstermiştir. Bu etkisini siklooksijenaz yolağında prostoglandin ve diğer yang1 yap1c1 mediyatörlerin oluşumunu inhibe ederek oluşturduğu bildirilmiştir (10).

Ayrica kapari bitkisinden elde edilen bioflavanoidlerin, Nükleer Faktör-Kappa B (NF-KB) aktivasyonunu önleyerek de anti-inflamatuar etkinlik gösterebileceği bildirilmiştir. NF$\mathrm{KB}$ inflamatuar sitokinlerin, kemokinlerin, hücre adhezyon moleküllerin, immünoreseptörlerin ekspresyonunun regüle edilmesinde önemli rol oynayan bir moleküldür (6).

Kapari bitkisinin anti-inflamatuar etkinliğine ek olarak aynı zamanda analjezik etkilerinin olduğu da tespit edilmiştir. Arslan ve Bektaş (9) C. ovatanın methanol ekstraktı ile fareler üzerinde yaptıkları bir çalışmada hem merkezi hem de periferal ağrı kesici etkiye sahip olduğunu tespit etmişlerdir. Bu ağr1 kesici etki naloksan ile antagonize edilerek merkezi ağrı kesici etkisi gösterilmiştir.

Kapari bitkisinin farklı ekstraktları kullanılarak yapılan çalışmalarda bu ekstraktların kısmi ve selektif antimikrobiyal aktivite gösterdiği tespit edilmiştir (4). C. spinosa dekoksiyonu kültür ortamına ilave edildiginde Dermococcus radophilus popülasyonunda önemli oranda azalma olurken, E. coli üzerine yapılan çalışmalarda herhangi bir antibakteriyel etkinliği olmadığ1 tespit edilmiştir $(11,13)$.

C. decidua tohumundan elde edilen ekstraktla yap1lan bir çalışmada Vibrio cholerae' ya karşı antibakteriyel aktivite gösterdiği tespit edilmiştir. C. zeylanica'nın eter ekstresi Stafilococcus aeurus, Bacillus subtilus, $p$-vulgaris bakterilerini inhibe ettiği gösterilmiştir (2). Ayrıca kapari ekstraktının Trikofiton türü mantarlara karş1 antifungal aktivitesinin olduğu gösterilmiştir. Antimikrobiyal ve antifungal potansiyel etkinin bitki içerisinde bulunan fenolik bileşiklere ve kuarterner amonyum ve glikosinolatlara bağl1 olabileceği bildirilmiştir $(2,8)$.

Antioksidanlar oksidatif strese maruz kalmasi sonucu hücreler tarafindan üretilen reaktif oksijen türleri ve serbest radikalleri süpürme kabiliyetine sahip bileşiklerdir (4). Hücre içinde üretilen reaktif oksijen türleri ve serbest radikaller canlılarda oksijen kullanımına bağlı olarak oluşan atık ürünlerdir. $\mathrm{Bu}$ ürünler hücre içerisinde hücre membranında bulunan polisatüre lipitler, DNA, proteinler ve enzimlerle reaksiyona girerek hücreye zarar verebilirler. Vücutta üretilen başlica serbest radikaller süperoksit anyonu, hidrojen peroksit $\left(\mathrm{H}_{2} \mathrm{O}_{2}\right)$, hidroksi anyonudur. Bununla birlikte dişarıdan alınan çeșitli kimyasallar, zehirler de vücutta biyotransformasyona uğrayarak reaktif oksijen türlerine ve serbest radikallere dönüşebilmektedir (28-30). Antioksidanlar reaktif oksijen türleri ve serbest radikallerle reaksiyona girerek bu ürünlerin zararlı etkilerini önlerler. Dolayisiyla antioksidan maddeler vücudun serbest radikallere karşı önemli bir savunma mekanizmasını oluşturur. Vitamin C (askorbik asit), alfa tokoferol (E vitamini), $\beta$-karoten, flavanoidler ve likopen gibi bileşikler vücuda dişarıdan alınarak antioksidan olarak kullanılır veya görev yaparlar. Dişarıdan alınan antioksidanlar vücudun kendi ürettiği antioksidan mekanizma yetersiz kaldığında serbest radikallerin süpürülmesinde ve oksidatif stresin önlenmesinde çok önemlidir (22, 29, 31).

Kapari bitkisinin içerisinde antioksidan ve biyoaktif moleküllerin olduğu çeşitli çalışmalarda gösterilmiştir. Bunların başlıca quercetin, fenolik bileşikler, glukosinolatlar, alkaloidler, flavanoidler, rutin, olmak üzere oldukça zengin bir antioksidan kaynağ1 olduğu gösterilmiştir $(18,28,30)$. Örneğin C. spinosa bitkisinin su ve ethanol ekstraktlarının doza bağlı olarak $\mathrm{Fe}^{+3} \ddot{\mathrm{u} \mathrm{Fe}} \mathrm{Fe}^{+2}$ ye indirgediği yine serbest radikal giderme aktivitesinin ölçümünde kullanılan 1,1 difenil-2-pikril-hidrazil (DPPH) metodunda DPPH konsantrasyonunu önemli ölçüde azalttığ1 ve güçlü bir $\mathrm{H}_{2} \mathrm{O}_{2}$ yakalama aktivitesine sahip olduğu gösterilmiştir. Yapılan bu çalışmalarda kaparinin içinde bulunan serbest fenolik bileşikler, flavanoidler ve karetenoidler, bu bitkinin antioksidan kapasitesiyle güçlü bir korelasyon göstermiştir (32, 33). Diğer taraftan oksidatif strese bağlı olarak görülen birtakım bozukluklarda da kapari bitkisinden elde edilen ekstraktların kullanımıla bu bozuklukların 
önlenebileceği gösterilmiştir. Yapılan bir çalışmada C. spinosanın ethanol özütününn in vitro olarak oksidatif strese bağlı oluşan deri sklerozisine karşı koruyucu olarak etkinliği gösterilmiştir (34). Nazıroğlu ve ark.(35) C. ovatanın ethanol özütünü kullanarak yaptıkları bir çalışmada C. ovata uygulamasının beyinde oluşturulan pentilentetrazol-indüklü oksidatif hasara karşı serbest radikal oluşumu ve epileptik atakları önleyerek koruyucu etki gösterdiğini tespit etmişlerdir. Aynı çalışmada C. ovata verilen grupta beyin korteksinde oluşan lipit peroksidasyon düzeyini pentilentetrazol verilen gruba göre önemli ölçüde azalttığ1 ve yine beyin korteksinde glutatyon seviyesini ve glutatyon peroksidaz aktivitesini artırdığ1 tespit edilmiştir.

Bütün bu çalışmalar kapari türünün kuvvetli antioksidan özellikler içerdiğini ve oksidatif stresle ilgili vücutta oluşan bozukluk ve hastalıklara karşı potansiyel bir terapötik ajan olarak kullanılabileceğini göstermektedir.

Kapari bitkisinin içerisinde bulunan biyolojik olarak aktif maddelerden karatenoidler, tokoferoller ve fenolik bileşiklerin antitümör etkisinin olduğu bilinmektedir. Bazı glukosinolatların örneğin benzyl-,p-hydroxybenzyl-, ve 2-hdroxybut-3-enyl gukosinolat kansere karşı kimyasal koruyucu olarak etkisinin bulunduğu rapor edilmiştir (27). Bilinen bu bileşiklerin haricinde yine değişik kapari türlerinden elde edilen $2 \mathrm{H}-1,4-$ benzoxazin-3(4H)-one, 6-methoxy-2methyl-4-carbaldehyde ve Cappamensin $A$, tümör inhibitörü olarak etki ettiği rapor edilmiştir. Cappamensin A'nın önemli ölçüde ovaryum, akciğer, meme, nazofarengeal ve ileosekal tümör hücre gruplarında antikanser aktivite gösterdiği tespit edilmiştir. C. spinosa meyve ekstraktının human hepoatoma HepG2 hücrelerinde antitümoral etkiye sahip olduğu bildirilmiştir (4).

Değişik kapari türlerinin antidiyabetik, immünomodülatör, diüretik, antiallerjik, antidiyaretik, antiviral, karaciğer koruyucu, anti-aterosklerotik, antifungal, antihipertansif, anthelmentik, antidepresant, diüretik ve hipolipidemik etkilerinin olduğu gösterilmiştir (1-3, 7-14).

C. spinosa meyvelerinden elde edilen ekstrakt1 Tip 2 diyabet hastalarında antihiperglisemik etki gösterdiği, açlik kan glukoz seviyesini ve glikozillenmiş hemoglobin seviyesini istatistiksel olarak kaper uygulaması almamış hastalara göre önemli ölçüde azalttığ1 tespit edilmiştir. Yine kapari uygulaması yapılmış hastalarda kan trigliserit seviyelerini istatistiksel olarak önemli miktarda düşürdüğü tespit edilmiştir. Kaparinin antidiyabetik ve hipolipidemik etki mekanizmas tam olarak tespit edilememiş olsada bu etkilerinin kaparinin içinde bulunan antioksidan bileşikler ve yine glukoz ve insülin mekanizması üzerinde olumlu etkileri olduğu bilinen Rutin ve lektinden kaynaklanabileceği ileri sürülmüştür (14). Ratlarda yapılan bir çalışmada C. spinosa'nın sudaki ekstraktı normal ve şiddetli hiperglisemik ratlarda potent lipit düşürücü etkiye sahip olduğu tespit edilmiştir (12). Tablo 3'de kapari türlerinin kullanılan kısımları, klinik kullanımı ve farmakolojik aktiviteleri verilmiştir.
Tablo 3 Kapari türlerinin kullanılan kısımları, klinik kullanımı ve farmakolojik aktiviteleri (1-3, 7-14).

\begin{tabular}{lll}
\hline Kullanılan Bölgeleri & $\begin{array}{l}\text { Farmakolojik } \\
\text { Kullanımı }\end{array}$ & $\begin{array}{l}\text { Farmakolojik } \\
\text { Aktivite }\end{array}$ \\
\hline Kökleri, Tomurcukları, & $\begin{array}{l}\text { Aterosklerosis, } \\
\text { Diyabet } \\
\text { İnflamasyon, }\end{array}$ & İmmunustimulan \\
Meyvesi, & $\begin{array}{l}\text { Sindirim } \\
\text { Sistemi }\end{array}$ & Antibakteriyel, \\
Kök Kabuğu, & Bozuklukları \\
Yaprakları, & & Astım, Kolesterol \\
Genç Sürgünler & & \\
\hline
\end{tabular}

\section{Kapari Bitkisinin Sinir Sistemi ve Nörodejeneratif Bozukluklardaki Etkileri}

Günümüzde sinir sistemini etkileyen birçok toksik, metabolik, genetik ve immün sistem kaynaklı faktör bulunmaktadır. Bu etkenlerin sinir sistemi üzerinde oluşturduğu hastalıklar ve bozukluklar günümüz tıbbında önemli bir sorun olarak görülmektedir. Zira sinir dokuda oluşan patolojik değişikliklerin ve bozuklukların düzeltilmesi, diğer doku ve sistemlerde görülen bozukluklara göre daha zor ve inatçı karakterde olduğu bilinmektedir. Bunlar arasında özellikle Multiple Skleroz (MS) gibi miyelin kaybiyla karakterize ve ilerleyici tipteki nörodejeneratif hastalıkların henüz tam bir tedavisi bulunmamaktadir (36). Multipl skleroz, merkezi sinir sisteminde beyaz cevherde kronik inflamatuar myelin kaybiyla karakterize ve MSS'ni etkileyen en yaygın nörolojik bozukluktur (37). Günümüzde MS için tam koruyucu ya da şifa sağlayııı bir tedavi yöntemi bilinmemektedir. Mevcut birçok tedavi, atak sıklığını azaltmayı, doğrudan atağa bağlanan sabit özürlülüğü önlemeyi, belirtilerin hafifletilmesini, ilerlemenin yol açtı̆̆1 özürlülügü ve sürekli kötüleşmeyi önlemeyi hedeflemektedir (38). Yapılan bazı çalışmalarda kapari familyasına ait bitki türlerinin yapısında bulunan çok sayıda biyoaktif bileşik sayesinde bu hastalıkların tedavisinde potansiyel olarak önemli bir terapötik ajan olarak değerlendirilmektedir (39). Özgün ve ark. (40) Deneysel Alerjik Ensefalomiyelit (DAE) ile oluşturulan deneysel multiple skleroz modelinde, C. ovata bitkisinin, meyve, tomurcuk ve çiçek kısımlarından elde edilen ekstrenin DAE gelişimini büyük ölçüde bastırdığını ve hastalık aktivitesi önemli bir șekilde inhibe ettiğini bildirmișlerdir. DAE'nin bu baskilanmasi, enflamatuar sinyal yolaklarında bulunan bazı genlerin ekspresyonunu önemli ölçüde düşürürken, miyelinasyona katılan genlerin ekspresyonunu arttırdı̆̆ını tespit etmişlerdir. Buna göre, kapari tedavisinin, DAE’nin gelişimini ertelediğini ve azalttığını ve farelerde kalıcı klinik bulgularla rahatsılığı iyileştirdiğini göstermişlerdir. Benzer bir başka çalışmada $C$. ovata ekstresinin, DAE oluşumu için yapılan immunizasyonun başlangıcında verildiğinde DAE'nin gelişimini büyük ölçüde bastırdığı ve hastalık aktivitesinin tamamen inhibe edildiği gözlenirken, hastalık belirtilerinin görüldüğü safhada uygulandığında, maksimum puan kontrol DAE grubuna göre anlamlı olarak azaldığı tespit edilmiştir (41). 
Bu etkilerin mekanizması ile ilgili olarak, C. ovata ekstresinin DAE'yi supresyonu, TNFa, IL6, NF-B, CCL5, CXCL9 ve CXCK10 gibi enflamatuar sinyallerde önemli olan genlerin azaltılmış ekspresyonu ile ilişkili olduğu tespit edilmiştir. Öte yandan, C. ovata ekstresinin miyelinasyon / remiyelinizasyonda rol oynayan genlerin ifadesini önemli ölçüde artırmıştır. İmmünohistokimyasal olarak $C$. ovata ekstresi ile tedavi edilen hayvanların beyinlerinde immün hücre infiltrasyonunda azalış tespit edilmiştir. C. ovata ekstresi tedavisinin, immün yanıt, enflamatuar yanıt, antijen işleme ve sunumu, B hücre aracilı immünite ve doğal immün yanıtta yer alan bir grup genin aşağ1 regülasyonuna neden olduğunu ortaya koyulmuştur (41).

Ozgun-Acar ve ark. (42) C. ovata bitkisinden izole edilen stigmast-5,22-dien-3 $\beta$-ol, myristate etken maddesinin human neuroblastoma hücre hattında (SH-SY5Y hücrelerinde) proinflamatuar veya enflamatuar sitokinlerin ve kemokinlerin ekspresyonlarını ve demyelinizasyon ve remyelinazyondaki rolünü araştırdığı bir çalışmada $C$. ovatadan izole edilen bu etken maddenin, proinflamatuar, enflamatuar sitokinlerin ve kemokinlerin ekspresyonlarını kontrol ile karşılaştırıldığında anlamlı şekilde aşağı doğru regüle ettiğini tespit etmiştir. Etken maddenin, Myelin temel protein (MBP), Myelin İlişkili Protein (MAG), Proteo lipit protein (PLP) ve super oksit dismutase (SOD) ekspresyon seviyelerini belirgin bir şekilde regüle edilmesinden dolayı miyelinde iyileşme etkisini gösterdiğini rapor etmişlerdir.

Kapari bitkisinin yukarıda belirtilen etkilerinin haricinde MSS' de görülen bazı bozukluklarda ki diğer etkileri değişik çalışmalarda gösterilmiştir. Bu çalışmalarda Kapari türlerinin sedatif, antikonvülsant, analjezik, antiepileptik etkilerinin de olduğu bildirilmiştir. C. deciduanın çiçek ve meyvelerinden elde edilmiş alkol ekstraktının pentilen tetrazol indüklü epilepsi modelinde epileptik atakları doza bağlı bir şekilde azalttı̆̆ı, aynı zamanda konvülsiyon gösteren hayvan sayısı ve artmış olan konvülsiyon latensini de düşürdüğü gösterilmiştir. Bu etkilerinden dolayı C. deciduanın merkezi sinir sistemi üzerine depresan ve antikonvülsan aktivitelerinin olduğu bildirilmiştir. Yine aynı çalışmalarda $C$. decidua ekstraktının barbitürat indüklü uyku testinde uyku latensini azaltıp uyku süresini arttırarak sedatif etkinlik gösterdiği tespit edilmiştir (1). Bir başka çalışmada, $C$. ovata bitkisinin etanol ekstraktının ratlarda pentilen tetrazol indüklü epilepsi modelinde beyinde pentilen tetrazol indüklü oksidatif toksik hasara karşı koruduğu ve lipid peroksidasyonunu azalttığ1, elektroensefalografide (EEG) görülen epileptiform deşarjlar1 ve spike (deşarj dalgası) sayısını düşürdüğü gösterilmiştir (35). C. ovatanın methanol ekstraktı ile fareler üzerinde yapılan bir çalışmada hem merkezi hem de periferal ağrı kesici etkiye sahip olduğu, bu ağn kesici etkinin naloksan ile antagonize edilerek C. ovatanın methanol ekstraktının merkezi ağrn kesici etkisi gösterilmiştir (9).

Diğer bazı çalışmalarda C. spinosa ektresinin Lipopolisakkarit-indüklü kronik öğrenme ve hafıza hasarına bağl1 hipokampus bölgesinde oluşan nörodejenerasyonu önemli ölçüde azalttığı, bu etkisi ile C. spinosanın bilişsel bozuklukları tedavi etmek için kullanılabileceği bildirilmiştir Goel ve ark.(43) beyinin diğer bir nörodejenaratif hastalığ1 olan Alzheimer hastalığ1 ile ilgili olarak, D-galaktoz indüklü deneysel Alzheimer hastalığ1 modelinde, Turgut ve ark., (44) C. spinosa bitkisinin methanol ekstresinin farelerde öğrenme bozukluklarını azalttığı ve hafızada tutma süresini önemli ölçüde artırdığını bildirmişlerdir.

\section{SONUÇ}

Bitkiler dünya genelinde medikal amaçla uzun y1llardır kullanılan ve geleneksel tıpta olduğu kadar modern tıp sisteminde de önemli bir yer işgal etmeye devam etmektedir. Modern sentetik ilaçlar ciddi sağlık sorunlarına yol açan çok sayıda yan etkiye neden olabilmektedir. Capparis türlerinin rapor edilmiş analjezik, anti-inflamatuar, antioksidan, antitümöral, diüretik, antidiyaretik, hipoglisemik, balgam söktürücü, antibakteriyel, antialerjik, antihipertansif, antifungal, antihiperlipidemik etkileri sahip olduğu bilinmektedir. Tıbbi olarak önemli ve besin açısından değerli olabilecek zengin bir içeriğe sahip kapari türleri son y1llarda bazı önemli nörodejeneratif hastalıklarda faydalı ve tedavi edici etkileri ile öne çıkmıştır. Capparis türlerinin bu etkileri insanlarda görülen ve henüz tam bir tedavi seçeneği bulunmayan nörodejeneratif hastalıkların tedavisi için umut verici olarak değerlendirilebilir.

\section{KAYNAKLAR}

1.Singh P, Mishra G, Sangeeta, Srivastava Shruti, Jha K. K, L. KR. Traditional uses, phytochemistry and pharmacological properties of Capparis decidua : An Overview. Pharm Lett. 2011;3(2):71-82.

2.Tlili N, Elfalleh W, Saadaoui E, Khaldi A, Triki S, Nasri N. The caper (Capparis L.): Ethnopharmacology, phytochemical and pharmacological properties. Fitoterapia. 2011;82(2):93101.

3.Tlili N, Khaldi A, Triki S, Munne-Bosch S. Phenolic Compounds and Vitamin Antioxidants of Caper (Capparis spinosa). Plant Food Hum Nutr. 2010;65(3):260-5.

4.Gull T, Anwar F, Sultana B, Alcayde MAC, Nouman W. Capparis species: A potential source of bioactives and high-value components: A review. Ind Crop Prod. 2015;67:81-96.

5.Duman E, Ozcan MM. Physicochemical properties of seeds of Capparis species growing wild in Turkey. Environ Monit Assess. 2014;186(4):2393-8.

6.Zhou HF, Xie CH, Jian RJ, Kang J, Li Y, Zhuang CL, et al. Biflavonoids from Caper (Capparis spinosa L.) Fruits and Their Effects in Inhibiting NF-kappa B Activation. J Agr Food Chem. 2011;59(7):3060-5.

7.Argentieri M, Macchia F, Papadia P, Fanizzi FP, Avato P. Bioactive compounds from Capparis spinosa subsp rupestris. Ind Crop Prod. 2012;36(1):65-9.

8.Ali-Shtayeh MS, Abu Ghdeib SI. Antifungal activity of plant extracts against dermatophytes. Mycoses. 1999;42(11-12):66572.

9.Arslan R, Bektas N. Antinociceptive effect of methanol extract of Capparis ovata in mice. Pharm Biol. 2010;48(10):118590. 
10.Bektas N, Arslan R, Goger F, Kirimer N, Ozturk Y. Investigation for anti-inflammatory and anti-thrombotic activities of methanol extract of Capparis ovata buds and fruits. J Ethnopharmacol. 2012;142(1):48-52.

11.Boga C, Forlani L, Calienni R, Hindley T, Hochkoeppler A, Tozzi S, et al. On the antibacterial activity of roots of Capparis spinosa L. Nat Prod Res. 2011;25(4):417-21. doi: 10.1080/14786419.2010.487189.

12.Eddouks M, Lemhadri A, Michel JB. Hypolipidemic activity of aqueous extract of Capparis spinosa L. in normal and diabetic rats. J Ethnopharmacol. 2005;98(3):345-50.

13.Gaind K. JT, Bhandarkar P. Volatile principle from seeds of Capparis decidua. Kinetics of in vitro antibacterial activity against Vibrio cholerae ogava, inaba, and eltor. Indian J Pharm. 1972;34:86-8.

14.Huseini HF, Hasani-Rnjbar S, Nayebi N, Heshmat R, Sigaroodi FK, Ahvazi M, et al. Capparis spinosa L. (Caper) fruit extract in treatment of type 2 diabetic patients: A randomized double-blind placebo-controlled clinical trial. Complement Ther Med. 2013;21(5):447-52.

15.Lassmann H, van Horssen J. The molecular basis of neurodegeneration in multiple sclerosis. Febs Lett. 2011;585(23):371523.

16.Inocencio C, Rivera D, Alcaraz F, Tomas-Barberan FA. Flavonoid content of commercial capers (Capparis spinosa, C-sicula and C-orientalis) produced in mediterranean countries. Eur Food Res Technol. 2000;212(1):70-4.

17.Moghaddasian B EA, Davood, Alaghemand A. Simultaneous determination of rutin and quercetin in different parts of Capparis spinosa. Bull Environ Pharmacol Life Sci. 2013;2:358 .

18.Sharaf M, ElAnsari MA, Saleh NAM. Flavonoids of four Cleome and three Capparis species. Biochem Syst Ecol. 1997;25(2):161-6.

19.Sharaf M, El-Ansari MA, Saleh NAM. Quercetin triglycoside from Capparis spinosa. Fitoterapia. 2000;71(1):46-9.

20.Fu XP, Wu T, Abdurahim M, Su Z, Hou XL, Aisa HA, et al. New spermidine alkaloids from Capparis spinosa roots. Phytochem Lett. 2008;1(1):59-62.

21.Ozcan M, Haciseferogullari H, Demir F. Some physico-mechanic and chemical properties of capers (Capparis ovata Desf. var. canescens (Coss.) Heywood) flower buds. J Food Eng. 2004;65(1):151-5.

22.Germano MP, De Pasquale R, D'Angelo V, Catania S, Silvari V, Costa C. Evaluation of extracts and isolated fraction from Capparis spinosa L. buds as an antioxidant source. J Agr Food Chem. 2002;50(5):1168-71.

23.Ao M, Gao Y, Yu L. Advances in studies on constituents and their pharmacological activities of Capparis spinosa. Chin Tradit Herb Drugs. 2007;38:463-7.
24.Ahmed ZF, Rizk AM, Hammouda FM, el-Nasr MM. Phytochemical investigation of Egyptian Capparis species. Planta medica. 1972;21(2):156-60.

25.Matthaus B, Ozcan M. Glucosinolate composition of young shoots and flower buds of capers (Capparis species) growing wild in Turkey. J Agric Food Chem. 2002;50(25):7323-5.

26.Anwar F, Latif S, Ashraf M, Gilani AH. Moringa oleifera: A food plant with multiple medicinal uses. Phytother Res. 2007;21(1):17-25.

27.Rathee S, Rathee P, Rathee D, Rathee D, V K. Phytochemical and pharmacological potential of kair (Capparis decidua). Int J Phytomed. 2011;2:10-7.

28.El-Ghorab A, Shibamoto T, Ozcan M. Chemical composition and antioxidant activities of buds and leaves of capers (Capparis ovata Desf. var. canescens) cultivated in Turkey. J Essent Oil Res. 2007;19(1):72-7.

29.'Tesoriere L, Butera D, Gentile C, Livrea MA. Bioactive components of caper (Capparis spinosa L.) from Sicily and antioxidant effects in a red meat simulated gastric digestion. J Agric Food Chem. 2007;55(21):8465-71.

30.Yang T, Wang C, Liu H, Chou G, Cheng X, Wang Z. A new antioxidant compound from Capparis spinosa. Pharm Biol. 2010;48(5):589-94.

31.Hammed AR, Abdel-Azim NS, Ismail SI, Hammouda FM. Chemical investigation of some Capparis species growing in Egypt and their antioxidant activity. Planta medica. 2007;73(9):942-.

32.Allaith AA. Assessment of the antioxidant properties of the caper fruit (Capparis spinosa L.) from Bahrain. JAAUBAS. 2016;19:1-7.

33.Nadaroğlu H DY, Demir N. Kapari (Capparis spinosa) Bitkisinin Antioksidan ve Antiradikal Özelliklerinin incelenmesi Türkiye 10 Gida Kongresi; Erzurum2008. p. 253-6.

34.Cao YL, Li X, Zheng M. Capparis spinosa protects against oxidative stress in systemic sclerosis dermal fibroblasts. Arch Dermatol Res. 2010;302(5):349-55.

35.Naziroglu M, Akay MB, Celik O, Yildirim MI, Balci E, Yurekli VA. Capparis ovata modulates brain oxidative toxicity and epileptic seizures in pentylentetrazol-induced epileptic rats. Neurochem Res. 2013;38(4):780-8. doi: 10.1007/s11064-0130978-3.

36.Di Biase A, Salvati S, Di Benedetto R, Attorri L, Martinelli A, Malchiodi F. Eicosapentaenoic acid pre-treatment reduces biochemical changes induced in total brain and myelin of weanling Wistar rats by cuprizone feeding. Prostag Leukotr Ess. 2014;90(4):99-104.

37.Hafler DA, Slavik JM, Anderson DE, O'Connor KC, De Jager P, Baecher-Allan C. Multiple sclerosis. Immunol Rev. 2005;204:208-31.

38.Eraksoy M, Akman G. Merkez sinir sisteminin miyelin has- 
talıkları. E. Ö, editor. İstanbul: Nobel Kitapevi; 2004. 505-35 p.

39.McMahon SB, Priestley JV. Peripheral neuropathies and neurotrophic factors: animal models and clinical perspectives. Curr Opin Neurobiol. 1995;5(5):616-24.

40.Ozgun O, Arslan S, Sen A. An efficient preparation for potential treatment of multiple sclerosis-Capparis ovata extract-MSCov: molecular results. Turk J Biochem. 2012;37:1201.

41.Ozgun-Acar O, Celik-Turgut G, Gazioglu I, Kolak U, Ozbal S, Ergur BU, et al. Capparis ovata treatment suppresses inflammatory cytokine expression and ameliorates experimental allergic encephalomyelitis model of multiple sclerosis in C57BL/ 6 mice. J Neuroimmunol. 2016;298:106-16.

42.Ozgun-Acar O, Gazioglu I, Kolak U, A S, G T. A potential therapeutic role in multiple sclerosis for stigmast-5,22-dien$3 \beta$-ol myristate isolated from Capparis ovata. EuroBiotech J. 2017;1(3).

43.Goel A, Digvijaya, Garg A, Kumar A. Effect of Capparis spinosa Linn. extract on lipopolysaccharide-induced cognitive impairment in rats. Indian J Exp. 2016;54(2):126-32.

44.Turgut NH, Kara H, Arslanbas E, Mert DG, Tepe B, Gungor H. Effect of Capparis spinosa L. on cognitive impairment induced by $\mathrm{D}$-galactose in mice via inhibition of oxidative stress. Turk J Med Sci. 2015;45(5):1127-36.

45.Canatan D. Kapari ile yapılmış bilimsel çalışmalar. Ayrıntı dergisi. 2009;1:60-7. 